\title{
UPAYA PERLINDUNGAN EKSPRESI BUDAYA TRADISIONAL DENGAN PEMBENTUKAN PERATURAN DAERAH
}

\author{
Bayangsari Wedhatami ${ }^{1}$, Budi Santoso ${ }^{2}$
}

\begin{abstract}
ABSTRAK
Penelitian bertujuan untuk mengetahui upaya perlindungan ekspresi budaya tradisional dengan melalui peraturan daerah. Secara spesifik ingin menjelaskan arti penting upaya perlindungan ekspresi budaya tradisional, menjelaskan kedudukan peraturan daerah tentang perlindungan ekspresi budaya tradisional dan menjelaskan materi muatan peraturan daerah tentang perlindungan ekspresi budaya tradisional. Metode pendekatan penelitian yang digunakan dalam penelitian ini adalah metode yuridis normatif dengan spesifikasi deskriptif analitis. Hasil penelitian ditemukan bahwa Ekspresi budaya tradisional perlu mendapatkan perlindungan hak kekayaan intelektual. Upaya pemerintah untuk melindungi ekspresi budaya tradisional dapat dilakukan dengan membentuk kebijakan perlindungan ekspresi budaya tradisional di daerah. Pentingnya pembentukan peraturan daerah perlindungan ekspresi budaya tradisional adalah sebagai kebijakan daerah yang melindungi hak kekayaan intelektual di bidang kebudayaan. Kedudukan peraturan daerah tentang perlindungan ekspresi budaya tradisional sebagai kebijakan daerah terhadap perlindungan ekspresi budaya tradisional harus tetap mengacu pada kerangka hukum hak kekayaan intelektual yang berlaku.
\end{abstract}

Kata Kunci: Perlindungan, Ekspresi Budaya Tradisional, Peraturan Daerah

\footnotetext{
${ }^{1}$ Mahasiswa Program Studi Magister IImu Hukum UNDIP

${ }^{2}$ Dosen Program Studi Magister Ilmu Hukum UNDIP
} 


\section{A. PENDAHULUAN}

\section{Latar Belakang}

Keanekaragaman suku, bahasa, adat dan kepercayaan yang ada di Indonesia, menjadikan Indonesia sebagai negara yang kaya akan budaya tradisional. Indonesia memiliki 1.128 suku yang tersebar di seluruh wilayah Indonesia dengan lebih dari 300 dialek bahasa daerah, lebih dari 3000 (tiga ribu) tarian asli Indonesia, dan terdapat berbagai kesenian lainnya seperti lagu tradisional, alat musik tradisional, seni tradisional, dan lain sebagainya. $^{3}$

Budaya tradisional merupakan suatu karya intelektual yang perlu mendapatkan perlindungan. Budaya tradisional adalah identitas dan jatidiri bangsa Indonesia yang dapat dimanfaatkan secara ekonomi demi kemajuan dan kesejahteraan masyarakat. Budaya tradisional merupakan suatu karya intelektual yang harus dilindungi. Salah satu bentuk karya intelektual dari budaya tradisional adalah ekspresi budaya tradisional atau expression of folklore.

Instrumen hukum nasional maupun internasional telah berusaha mengatur tentang perlindungan terhadap ekspresi budaya tradisional. Ditinjau dari perspektif hak kekayaan intelektual, rezim hak kekayaan intelektual yang digunakan di Indonesia sebagai instrumen perlindungan ekspresi budaya tradisional adalah rezim hak cipta. Undang-Undang Hak Cipta memberikan perlindungan kekayaan intelektual bagi seni dan budaya tradisional Indonesia. Sebagaimana disebutkan dalam Pasal 10 ayat (2) disebutkan bahwa: "negara memegang Hak Cipta atas folklor dan hasil kebudayaan rakyat yang menjadi milik bersama, seperti cerita, hikayat, dongeng, legenda, babad, lagu, kerajinan tangan, koreografi, tarian, kaligrafi, dan karya seni lainnya."

Pasal 12 ayat (1) Undang-Undang Nomor 19 Tahun 2002 tentang Hak Cipta mengatur bahwa ciptaan yang dilindungi meliputi ciptaan: Buku, program computer, pamphlet, perwajahan (lay out) karya tulis yang diterbitkan, dan semua hasil karya tulis lain; Ceramah, kuliah, pidato, dan

\footnotetext{
${ }^{3}$ Kompilasi data dari www.wikipedia.com diakses tanggal 30 Desember 2013
} 
Ciptaan lain yang sejenis dengan itu; Alat peraga yang dibuat untuk kepentingan pendidikan dan ilmu pengetahuan; Lagu atau musik dengan atau tanpa teks; Drama atau drama musikal, tari, koreografi, pewayangan, dan pantomime; Seni rupa dalam segala bentuk seperti seni lukis, gambar, seni ukir, seni kaligrafi, seni pahat, seni patunng, kolase, dan seni terapan; Arsitektur; Peta; Seni batik; Fotografi; Sinematografi; Terjemahan, tafsir, saduran, bunga rampai, database, dan karya lain dari hasil pengalihwujudan.

Undang-Undang Nomor 19 Tahun 2002 tentang Hak Cipta belum dapat memberikan perlindungan terhadap ekspresi budaya tradisional secara maksimal. Kelemahan Undang-Undang Nomor 19 Tahun 2002 tentang Hak Cipta dan persoalan belum adanya data nasional yang dapat menunjukkan jumlah seluruh budaya tradisional yang ada di Indonesia menyebabkan terjadinya klaim oleh negara lain atas budaya tradisional milik Indonesia.

Kementerian Pendidikan dan Kebudayaan memiliki data yang menunjukkan bahwa terdapat 2644 karya budaya takbenda di Indonesia, namun baru 77 yang telah ditetapkan secara resmi sebagai warisan budaya takbenda Indonesia, termasuk enam diantaranya telah ditetapkan lebih dulu sebagai Warisan Dunia oleh UNESCO yaitu, Wayang, Keris, Batik, Angklung, Tari Saman dan Noken. ${ }^{4}$

Kekayaan budaya asli Indonesia yang diklaim sebagai milik negara lain jumlahnya mencapai 34 (tiga puluh empat) jenis budaya. ${ }^{5}$ Beberapa budaya tradisional Indonesia yang diakui oleh negara lain sebagai budayanya antara lain adalah Tari Reog Ponorogo, Lagu Rasa Sayange, Tari Pendet. ${ }^{6}$

Kekayaan yang berbasis budaya tradisional mempunyai nilai ekonomi yang sangat tinggi. Upaya perlindungan terhadap ekspresi budaya traadisional tentunya akan mendorong peningkatan perekonomian Indonesia dan dapat meningkatkan kesejahteraan masyarakat. Komitmen Pemerintah, Pemerintah Daerah, maupun masyarakat diperlukan dalam mengupayakan perlindungan

\footnotetext{
${ }^{4}$ Maya Sofia dan Tasya Paramitha, Upaya Pemerintah Agar Budaya Indonesia Tak Diklaim Negara Lain, diakses dari www.life.viva.co.id pada tanggal 22 Desember 2013

5 www.portalindonesiaku.blogspot.com, Data Budaya Indonesia yang Diklaim Negara Lain, diakses pada tanggal 23 Desember 2013

${ }^{6}$ www.antaranews.com, Warisan Budaya Indonesia Rawan Diklaim Negara Lain, diakses pada tanggal 23 Desember 2013
} 
terhadap ekspresi budaya tradisional Indonesia. Perlindungan yang maksimal terhadap ekspresi budaya tradisional membutuhkan kerjasama yang baik antara Pemerintah dengan Pemerintah Daerah. Pemerintah Daerah baik pada tingkat provinsi atau kabupaten/kota perlu merumuskan suatu kebijakan daerah terkait perlindungan terhadap budaya tradisional.

Berdasar pada latar belakang yang telah diuraikan diatas, maka masalah yang akan diteliti adalah seputar mengapa perlindungan ekspresi budaya tradisional perlu diatur dalam peraturan daerah, bagaimana kedudukan peraturan daerah perlindungan ekspresi budaya tradisional dalam instrumen hukum hak kekayaan intelektual, dan hal apa yang perlu diatur dalam peraturan daerah perlindungan ekspresi budaya tradisional.

\section{Metode Penelitian}

Metode pendekatan penelitian yang digunakan dalam penelitian ini adalah metode yuridis normatif dengan spesifikasi deskriptif analitis. Penulisan hukum ini pertama-tama mengkaji segala ketentuan peraturan perundang-undangan berkaitan dengan perlindungan hak kekayaan intelektual, perlindungan terhadap ekspresi budaya tradisional dan pembentukan peraturan daerah. Hasil penelitian ini akan benar-benar menjadi suatu deskripsi dari objek yang menjadi permasalahan yaitu upaya perlindungan ekspresi budaya tradisional dengan pembentukan peraturan daerah perlindungan kekayaan intelektual.

\section{Kerangka Teori}

Ada dua teori yang secara filosofis terkait dengan anggapan bahwa hak kekayaan intelektual adalah suatu sistem kepemilikan. Teori tersebut dikemukakan oleh John Locke dan Hegel. Baik John Locke maupun Hegel berawal dari Teori Hukum Alam yang bersumber pada moralitas tentang apa yang baik dan yang buruk. ${ }^{7}$ Teori Hukum Alam dengan salah satu tokohnya yaitu Thomas Aquinas menganggap hukum sebagai suatu yang universal dan hidup dalam setiap sanubari seseorang. Hukum harus tunduk

\footnotetext{
${ }^{7}$ Satjipto Raharjo, Ilmu Hukum, (Bandung: Citra Aditya Bakti, 2000), hal 266
} 
pada batasan-batasan moral yang bersifat Ketuhanan berdasarkan akal budi manusia. $^{8}$

John Locke mengajarkan konsep kepemilikan (property) kaitannya dengan hak asasi manusia dengan pernyataannya "Life, Liberty, Property." Locke mengatakan bahwa milik dari seorang manusia terhadap benda yang dihasilkannya itu sudah ada sejak manusia itu lahir. Benda dalam pengertian di sini tidak hanya benda yang berwujud, tetapi juga yang abstrak, yang disebut dengan hak milik benda tak berwujud, yang merupakan hasil dari intelektualitas manusia. ${ }^{9}$

Hegel mengembangkan konsep tentang "Right, Ethic and State" yang intinya sebagai eksistensi dari kepribadian. Pemikiran Hegel menjadi dasar pembenaran hak kekayaan intelektual bahwa ada sesuatu yang lebih dalam kekayaan (property) dari sekedar perilaku insting manusia. ${ }^{10}$ Pentingnya kekayaan (property) sebagai salah satu cara untuk membangun, mengembangkan dan memahami kepribadian seseorang, ekspresi yang hendak dikuasai, sekaligus menetapkan batasan antara pribadi lain dan kekayaan lain dari masyarakat.

Penelitian ini juga berdasar pada teori pembentukan peraturan perundang-undangan yang dikemukakan oleh Hans Kelsen dan Hans Nawiasky. Hans Kelsen dengan Stufentheorie menyebutkan bahwa normanorma hukum itu berjenjang-jenjang dan berlapis-lapis dalam suatu hierarki tata susunan, dimana norma yang lebih rendah berlaku, bersumber, dan berdasar pada norma yang lebih tinggi, norma yang lebih tinggi berlaku, bersumber dan berdasar pada norma yang lebih tinggi lagi. ${ }^{11}$ Sejalan dengan pemikiran Kelsen tentang norma yang berlapis-lapis dan berjenjang, Hans Nawiasky mengemukakan bahwa selain norma itu berlapis-lapis dan berjenjang-jenjang, norma hukum dari suatu negara itu juga berkelompokkelompok yang terdiri dari kelompok Staatsfundamentalnorm (Norma Fundamental Negara), Staatsgrundgesetz (Aturan Dasar Negara), Formell

\footnotetext{
${ }^{8}$ W.Friedman, Teori dan Filsafat Hukum, (Jakarta: CV Rajawali), hal 62

${ }^{9}$ Syafrinaldi, Sejarah dan Teori Perlindungan Hak Kekayaan Intelektual, Al Mawarid edisi IX Tahun 2003, hal 6

${ }^{10}$ Rahmi Jened, 2010, Hak Kekayaan Intelektual, Surabaya: Penerbit Universitas Airlangga hal21

${ }^{11}$ Hans Kelsen, Teori Umum tentang Hukum dan Negara, (Bandung: Nusa Media, 2013) hal113
} 
Gesetz (Undang-Undang “formal”), dan Verordnung \& Autonome Satzung (Aturan pelaksana dan aturan otonom). ${ }^{12}$

\section{B. HASIL PENELITIAN DAN PEMBAHASAN}

\section{Pentingnya Pembentukan Peraturan Daerah tentang Perlindungan Ekspresi Budaya Tradisional}

Keanekaragaman suku, bahasa, adat dan kepercayaan yang ada di Indonesia, menjadikan Indonesia sebagai negara yang kaya akan budaya tradisional. Kekayaan budaya tersebut menyimpan potensi ekonomi yang sangat besar sehingga dapat mendukung proses pembangunan ekonomi yang berkelanjutan. Tidak mengherankan bahwa nilai tersebut telah menyebabkan pihak asing berulangkali memanfaatkan tanpa izin dan/atau mengakui budaya tradisional di Indonesia sebagai milik mereka.

Klaim negara lain terhadap budaya tradisional Indonesia dapat merugikan kepentingan nasional karena semakin lama akan semakin banyak budaya tradisonal Indonesia yang diambil alih oleh bangsa lain, sedangkan masyarakat Indonesia sendiri tidak mendapat keuntungan dari karya intelektual warisan budaya Indonesia tersebut. Sebagai suatu karya intelektual, karya seni dan budaya tradisional sudah seharusnya mendapatkan perlindungan hak kekayaan intelektualnya.

Hak kekayaan intelektual merupakan satu bentuk hasil berpikir manusia yang kemudian diterjemahkan ke dalam sebuah ciptaan atau temuan. Hal yang paling mendasar bagi perlindungan hak kekayaan intelektual adalah bahwa seseorang yang telah mencurahkan usahanya untuk menciptakan atau menemukan sesuatu selanjutnya mempunyai hak alamiah untuk mengontrol apa-apa yang diciptakannya. ${ }^{13}$

Hak kekayaan intelektual memang menjadikan karya-karya yang timbul atau lahir karena kemampuan intelektual manusia sebagai inti dan objek pengaturannya. Karya tersebut di dalamnya terdapat unsur

\footnotetext{
${ }^{12}$ Hans Nawiasky dalam Maria Farida Indrati, 2006, Ilmu Perundang-undangan- Dasar-dasar dan Pembentukannya, Yogyakarta: Kanisius hal 27

${ }^{13}$ Suyud Margono, 2010, Hukum Hak Cipta Indonesia: Teori dan Analisis Harmonisasi Ketentuan WTO-TRIPs Agreement, Bogor: Ghalia Indonesia hal 14
} 
pembangunan yang berasal dari akal, dan dengan ini manusia dapat mengembangkan dan memanfaatkannya guna kesejahteraan hidupnya. Hak kekayaan intelektual dapat memberikan manfaat ekonomi apabila temuan atau ciptaan tersebut digunakan oleh orang lain dalam aktivitas yang bersifat komersial. $^{14}$

Dari perspektif hak kekayaan intelektual, instrumen perlindungan ekspresi budaya tradisional di Indonesia menggunakan rezim hak cipta. Hak cipta adalah bagian dari sekumpulan hak yang dinamakan hak kekayaan intelektual yang pengaturannya terdapat dalam ilmu hukum hak kekayaan intelektual. Hak cipta adalah sejenis kepemilikan pribadi atas suatu ciptaan yang berupa perwujudan dari suatu ide pencipta di bidang seni, sastra, dan ilmu pengetahuan. ${ }^{15}$

Beberapa instrumen hukum internasional telah mengatur tentang hak cipta pada umumnya dan perlindungan ekspresi budaya tradisional pada khususnya. Terdapat beberapa konvensi Internasional yang yang mengatur perlindungan budaya tradisional antara lain Berne Convention, The Model Provision 1982, dan Refised Draft Provisions for The Protection of Traditional Cultural Expression/Expression of Folklore. ${ }^{16}$

Menurut Undang-Undang Nomor 19 Tahun 2002 tentang Hak Cipta, budaya tradisional termasuk dalam karya ciptaan yang dilindungi. Hal ini ditegaskan dalam Pasal 10 dan Pasal 12. Pasal 10 Undang-Undang Nomor 19 Tahun 2002 mengatur tentang folklor dalam hal pemegang Hak Cipta, yakni:

ayat (1) "Negara memegang Hak Cipta atas karya peninggalan prasejarah, sejarah, dan benda budaya nasional lainnya"; ayat (2) "Negara memegang Hak Cipta atas folklor dari hasil kebudayaan rakyat yang menjadi milik bersama seperti cerita, hikayat, dogeng, legenda, babad, lagu, kerajinan tangan,

\footnotetext{
${ }^{14}$ Arif Lutviansori, 2010, Hak Cipta dan Perlindungan Folklor di Indonesia, Yogyakarta: Graha Ilmu hal. 43

${ }^{15}$ Tim Lindsey,dkk (ed.), 2011, Hak Kekayaan Intelektual Suatu Pengantar, Bandung: PT Alumni hal. 96

16 WIPO Publication, Consolidated Analysis of The Legal Protection of Traditional Cultural Expression/Expression of Folklore, May 2003, hal. 21-24
} 
koreografi, tarian, kaligrafi dan karya seni lainnya." Selanjutnya Penjelasan undang-undang tersebut memberikan definisi folklor sebagai sekumpulan ciptaan tradisional, baik oleh sekelompok maupun perorangan dalam masyarakat yang menunjukkan identitas sosial dan budayanya berdasarkan standar nilai-nilai yang diucapkan atau diikuti secara turun menurun, termasuk: 1. cerita rakyat, puisi rakyat; 2. lagu-lagu rakyat dan musik instrumen tradisional; 3. tarian-tarian rakyat, permainan tradisional; 4. hasil seni antara lain berupa: lukisan, gambar, ukir-ukiran, pahatan, mosaik, perhiasan, kerajinan tangan, pakaian, instrumen musik, dan tenun tradisional.

Dalam Pasal 12 ditegaskan pula bahwa karya ciptaan yang dilindungi oleh undang-undang ini adalah ciptaan dalam bidang ilmu pengetahuan, seni, dan sastra, yang mencakup: buku, pogram komputer, pamflet, perwajahan (lay out) karya tulis yang diterbitkan, dan semua hasil karya tulis lain; ceramah, kuliah, pidato, dan ciptaan lain yang sejenis dengan itu; alat peraga yang dibuat untuk kepentingan pendidikan dan ilmu pengetahuan; lagu atau musik dengan atau tanpa teks; drama atau drama musikal, tari, koreografi, pewayangan, dan pantomim; seni rupa dalam segala bentuk seperti seni lukis, gambar, seni ukir, seni kaligrafi, seni pahat, seni patung, kolase, dan seni terapan; arsitektur; peta; seni batik; fotografi; dan sinematografi.

Dalam Undang-Undang Nomor 19 Tahun 2002 tentang Hak Cipta, masih belum terfokus bagaimana konsep perlindungan terhadap ekspresi budaya tradisional. Hal ini diungkapkan pula oleh P.V Valsala G Kutty dalam penelitiannya tentang Indonesia yang dipublikasikan oleh WIPO, bahwa $^{17}$ :

In the absence of detailed regulations, as provided for under the Copyright Act, there is a vacuum in the legal

P.V Valsala G Kutty, National Experiences With The Protection of Expression of Folklore/Traditional Cultural Expression, WIPO Publication hal. 31 
framework for the implementation of copyright protection for cultural products representing communal properties. It is not clear as to what mechanism will be developed for the commercial or other use of cultural products by foreigners, and whether any fair uses will be contemplated, and in addition, if any royalty will be prescribed to be paid for use of such cultural products. If such a mechanism is developed, to which agency would payment be made?

Kelemahan Undang-Undang Hak Cipta dalam melindungi budaya tradisional Indonesia, memberikan kontribusi pada lemahnya perlindungan budaya tradisional di Indonesia. Pemerintah, Pemerintah Daerah, maupun masyarakat harus berkomitmen untuk melakukan upaya perlindungan ekspresi budaya tradisional.

Di era otonomi daerah, peran pemerintah daerah dalam mengelola budaya tradisional sebagai aset intelektual daerah menjadi terbuka seiring dengan berlakunya Undang-Undang Nomor 32 tahun 2004 tentang Pemerintahan Daerah. Pasal 13 ayat (1) Undang-Undang Nomor 32 Tahun 2004 tentang Pemerintahan Daerah menyatakan bahwa:

"urusan wajib yang menjadi kewenangan pemerintahan daerah provinsi merupakan urusan dalam skala provinsi yang meliputi perencanaan dan pengendalian pembangunan; ...; dan urusan wajib lainnya yang diamanatkan oleh peraturan perundang-undangan."

Hal serupa juga berlaku bagi Pemerintah Kabupatan/Kota sebagaimana diatur dalam Pasal 14 ayat (1). Dari ketentuan tersebut dapat disimpulkan bahwa pemerintah daerah memiliki peranan penting dalam mengelola potensi ekspresi budaya tradisional yang ada di daerahnya, dan diharapkan pengelolaan tersebut dapat berdampak positif terhadap peningkatan kesejahteraan masyarakat di daerah yang bersangkutan. 
Dalam Peraturan Pemerintah Nomor 38 Tahun 2007 tentang Pembagian Urusan Pemerintahan Antara Pemerintah, Pemerintahan Daerah Provinsi dan Pemerintahan Daerah Kabupaten/Kota, yang merupakan peraturan pelaksana dari Undang-Undang Nomor 32 Tahun 2004, dalam Pasal 2 ayat (4) huruf q menyebutkan bahwa urusan pemerintahan daerah provinsi dan kabupaten/kota meliputi bidang urusan kebudayaan dan pariwisata. Selanjutnya dalam Pasal 7 ayat (2) huruf w menyebutkan bahwa urusan wajib yang wajib diselenggarakan oleh pemerintahan daerah provinsi dan pemerintahan daerah kabupaten/kota berkaitan dengan pelayanan dasar salah satunya adalah kebudayaan.

Lampiran Peraturan Pemerintah Nomor 38 Tahun 2007 membedakan pembagian urusan pemerintahan di bidang kebudayaan dan pariwisata, khususnya untuk sub bidang kebudayaan menjadi tiga urusan yaitu urusan Pemerintah, urusan Pemerintah Daerah Provinsi dan Daerah Kabupaten/Kota.

Urusan bidang kebudayaan yang menjadi urusan pemerintah pusat dalam angka 2 adalah perlindungan Hak kekayaan intelektual (HKI) di bidang kebudayaan. Pemerintah daerah provinsi memiliki urusan dalam hal pelaksanaan kebijakan nasional dan penetapan kebijakan provinsi mengenai perlindungan HKI bidang kebudayaan. Sedangkan untuk pemerintah daerah kabupaten/kota, memiliki urusan dalam hal pelaksanaan kebijakan nasional/provinsi dan penetapan kebijakan kabupaten/kota mengenai perlindungan HKI bidang kebudayaan. Oleh sebab itu, pada tingkat daerah juga diperlukan peraturan hukum yang mengatur tentang perlindungan ekspresi budaya tradisional di daerah sebagai implementasi kebijakan daerah mengenai perlindungan hak kekayaan intelektual di bidang kebudayaan.

\section{Kedudukan Peraturan Daerah tentang Perlindungan Ekspresi Budaya} Tradisional Dalam Instrumen Hukum Hak Kekayaan Intelektual di Indonesia 
Peraturan daerah merupakan salah satu jenis peraturan perundangundangan di Indonesia yang diatur dalam Undang-Undang Nomor 12 Tahun 2011 tentang Pembentukan Peraturan Perundang-undangan. Setiap peraturan perundang-undangan di Indonesia memiliki kedudukan dan kekuatan hukum sesuai dengan hirarki peraturan perundang-undangan.

Pembentukan peraturan daerah tentang perlindungan ekspresi budaya tradisional harus tetap bersumber pada peraturan yang lebih tinggi yaitu Undang-Undang Dasar Negara Republik Indonesia Tahun 1945 dan undang-undang. Hal ini bertujuan untuk mewujudkan harmonisasi dan sinkronisasi antara peraturan perundang-undangan yang satu dengan yang lain.

Kedudukan peraturan daerah tentang perlindungan ekspresi budaya tradisional adalah sebagai aturan otonom yang mengatur kebijakan perlindungan hak kekayaan intelektual di bidang kebudayaan. Peraturan daerah tentang perlindungan ekspresi budaya tradisional sebagai aturan otonom memang tidak diharuskan memiliki kesesuaian substansi dengan peraturan perundang-undangan yang lebih tinggi, akan tetapi sebagai bagian dari sistem hukum hak kekayaan intelektual hendaknya pengaturan pemanfaatan dan perlindungan ekspresi budaya tradisional tetap berada pada kerangka hukum hak kekayaan intelektual yang berlaku baik secara nasional maupun internasional.

Peraturan daerah tentang perlindungan ekspresi budaya tradisional tetap harus memperhatikan kesesuaian norma atau materi muatan peraturan daerah dengan peraturan perundang-undangan lain yang mengatur hukum hak kekayaan intelektual pada umumnya dan hak cipta pada khususnya. Materi muatan yang diatur dalam peraturan daerah tentang perlindungan ekspresi budaya tradisional tidak boleh bertentangan dengan prinsip-prinsip perlindungan hukum kekayaan intelektual yang diatur dalam Perjanjian TRIPs, Konvensi Berne, dan Undang-Undang Nomor 19 Tahun 2002 tentang Hak Cipta. 


\section{Materi Muatan Peraturan Daerah tentang Perlindungan Ekspresi Budaya Tradisional Dalam Instrumen Hukum Hak Kekayaan Intelektual di Indonesia}

Hal-hal pokok yang perlu diatur dalam batang tubuh peraturan daerah tentang perlindungan ekspresi budaya tradisional mencakup:

\section{a. Pengertian}

Peraturan daerah tentang perlindungan ekspresi budaya tradisional perlu merumuskan batasan definisi yang jelas terhadap istilah ekspresi budaya tradisional. Istilah pengetahuan tradisional dalam peraturan daerah tentang perlindungan ekspresi budaya tradisional sebaiknya merumuskan batasan definisi ekspresi budaya tradisional dalam ketentuan umum yang mendefinisikan ekspresi budaya tradisional sebagai kebudayaan karya intelektual dalam bidang seni, termasuk ekspresi sastra yang mengandung unsur karakteristik warisan tradisional yang dihasilkan, dikembangkan, dan dipelihara oleh kustodiannya.

\section{b. Lingkup ciptaan yang dilindungi}

Peraturan daerah tentang perlindungan ekspresi budaya tradisional perlu merumuskan secara jelas lingkup ekspresi budaya tradisional yaitu bentuk ciptaan yang dilindungi dalam peraturan daerah. Peraturan daerah tentang perlindungan ekspresi budaya tradisional sebaiknya mengatur secara lebih rinci tentang bentuk ekspresi budaya tradisional yang mendapatkan perlindungan.

\section{c. Kepemilikan ekspresi budaya tradisional}

Peraturan daerah tentang perlindungan ekspresi budaya tradisional perlu merumuskan secara jelas kepemilikan ekspresi budaya tradisional sehingga dapat menentukan siapa saja pihak yang berhak untuk memperoleh manfaat dari pemanfaatan ekspresi budaya tradisional.

Eksistensi ekspresi budaya tradisional tidak dapat dipisahkan dari masyarakat adat atau komunitas lokal yang mengembangkan dan melestarikannya, oleh sebab itu pemilik sah ekspresi budaya tradisional adalah masyarakat adat dan komunitas lokal setempat. Masyarakat adat memiliki hak material maupun nonmaterial atas sumber daya tradisional 
yang dikelola secara komunal berdasarkan kepemilikan bersama. Tidak ada seorangpun yang berhak memonopoli secara eksklusif atas pemanfaatan ekspresi budaya tradisional serta memperoleh keuntungan dari pemanfaatan tersebut tanpa ijin dari pemilik ekspresi budaya tradisional.

Prinsip hak kepemilikan dan hak pemangkuan ekspresi budaya tradisional adalah sebagai berikut: Hak milik atas sumber daya budaya tradisional yang berasal dari hak-hak tradisional yang masih hidup, dipegang oleh masyarakat tradisional termasuk kesatuan masyarakat hukum adat terkait; Hak penguasaan atas sumber daya budaya tradisional dalam yurisdiksi wilayah suatu bangsa, dipegang oleh negara; Hak pengelolaan atas sumber daya budaya tradisional dipegang oleh Pemerintah sebagai otoritas di tingkat nasional, atau otoritas di tingkat bawahnya yang menerima delegasi kewenangan untuk itu.

\section{d. Pemanfaatan}

Peraturan daerah tentang perlindungan ekspresi budaya tradisional perlu mengatur mekanisme pemanfaatan atas ekspresi budaya tradisional. Peraturan daerah tentang perlindungan ekspresi budaya tradisional perlu mengatur ketentuan izin pemanfaatan atas penggunaan ekspresi budaya tradisional untuk kepentingan komersial. Izin akses pemanfaatan adalah izin yang diberikan kepada orang asing atau badan hukum asing atau badan hukum Indonesia penanaman modal asing, untuk melakukan pemanfaatan kekayaan intelektual.

Setiap orang yang akan melakukan pemanfaatan untuk tujuan komersial, wajib memiliki izin akses pemanfaatan dan perjanjian pemanfaatan dari pemilik/pemegang kekayaan intelektual dan hak terkait atau dari Pemerintah Daerah. Setiap orang yang memanfaatkan ekspresi budaya tradisional untuk kepentingan komersial wajib melakukan pembagian hasil pemanfaatan kepada pemilik/pemegang kekayaan intelektual dan hak terkait atau Pemerintah Daerah, kecuali diperjanjikan lain. 
Pemerintah Daerah sebagai pemegang Hak Cipta atas ekspresi budaya tradisional dapat menentukan royalti terhadap pemanfaatan ekspresi budaya tradisional oleh pihak asing. Pemanfaatan oleh pihak asing dilakukan melalui perjanjian pemanfaatan, dengan mempertimbangkan kepentingan Daerah. Royalti tersebut merupakan pendapatan Daerah, dan disetorkan sepenuhnya ke Kas Daerah.

Undang-Undang Nomor 19 Tahun 2002 tentang Hak Cipta mengatur pembatasan hak cipta atas penggunaan ciptaan oleh pihak lain untuk kepentingan pendidikan, penelitian, penulisan karya ilmiah, penyusunan laporan, penulisan kritik atau tinjauan suatu masalah dengan tidak merugikan kepentingan yang wajar dari Pencipta.

\section{e. Perlindungan}

Peraturan daerah tentang perlindungan ekspresi budaya tradisional perlu mengatur sistem perlindungan ekspresi budaya tradisional. Perlindungan terhadap ekspresi budaya tradisional diberikan untuk unsur budaya yang memiliki karakteristik khusus yang terintegrasi dengan identitas budaya masyarakat tertentu yang melestarikannya; dan disusun, dikembangkan, diterapkan, dan dipelihara dalam lingkup tradisi.

Perlindungan terhadap ekspresi budaya tradisional dapat dilakukan dengan cara: inventarisasi, dokumentasi, dan pemeliharaan; pencegahan dan/atau pelarangan; dan pembinaan.

\section{f. Larangan dan Sanksi}

Peraturan daerah tentang perlindungan ekspresi budaya tradisional perlu mengatur bahwa perlindungan atas ekspresi budaya tradisional oleh Pemerintah Daerah dengan membatasi akses, pencegahan dan pelarangan kepada pihak asing terhadap ekspresi budaya tradisional (folklore). Pemerintah Daerah melakukan perlindungan ekspresi budaya tradisional (folklore) yang dimanfaatkan oleh pihak asing, berupa pencegahan dan/atau pelarangan terhadap :

1) pemanfaatan pengetahuan tradisional yang dilakukan oleh badan hukum, tanpa izin akses pemanfaatan dan perjanjian pemanfaatan; 
2) pemanfaatan ekspresi budaya tradisional (folklore) dan/atau pengetahuan tradisional yang dilakukan oleh perorangan dan/atau badan hukum, yang dalam pelaksanaan pemanfaatannya tidak menyebutkan dengan jelas asal wilayah ekspresi budaya tradisional (folklore) serta kustodiannya, yang menjadi sumber dan pemilik ekspresi budaya tradisional (folklore) tersebut; dan/atau

3) pemanfaatan ekspresi budaya tradisional (folklore) yang dilakukan oleh perorangan atau badan hukum, yang dilakukan secara tidak patut, menyimpang dan menimbulkan kesan tidak benar terhadap masyarakat terkait, atau yang membuat masyarakat merasa tersinggung, terhina, tercela, dan/atau tercemar.

Peraturan daerah tentang perlindungan ekspresi budaya tradisional perlu merumuskan ketentuan sanksi atas larangan. Pelanggaran terhadap larangan dalam konteks perlindungan ekspresi budaya tradisional masuk dalam kategori tindak pidana pelanggaran. Pasal 15 ayat (2) UndangUndang Nomor 12 Tahun 2011 tentang Pembentukan Peraturan Perundang-undangan merumuskan bahwa ketentuan pidana pada Peraturan Daerah berupa ancaman pidana kurungan paling lama 6 (enam) bulan atau denda paling namyak Rp. 50.000.000,00 (lima puluh juta rupiah) atau sesuai ketentuan peraturan perundang-undangan.

\section{SIMPULAN DAN SARAN}

1. Perlu memberikan Perlindungan Ekspresi Budaya Tradisional melalui pembentukan Peraturan Daerah. Perlindungan Ekspresi budaya tradisional merupakan perlindungan terhadap identitas dan jatidiri suatu bangsa. Selain itu juga sebagai implementasi kebijakan daerah mengenai mekanisme pemanfaatan dan perlindungan hak kekayaan intelektual di bidang kebudayaan.

2. Kedudukan peraturan daerah tentang perlindungan ekspresi budaya tradisional adalah sebagai aturan otonom yang mengatur kebijakan perlindungan hak kekayaan intelektual di bidang kebudayaan. Peraturan daerah tersebut diharuskan memiliki kesesuaian substansi dengan peraturan 
perundang-undangan yang lebih tinggi, akan tetapi sebagai bagian dari sistem hukum hak kekayaan intelektual hendaknya pengaturan pemanfaatan dan perlindungan ekspresi budaya tradisional tetap berada pada kerangka hukum hak kekayaan intelektual yang berlaku baik secara nasional maupun internasional.

3. Materi muatan peraturan daerah tentang ekspresi budaya tradisional perlu memuat tentang pengertian ekspresi budaya tradisional, bentuk ciptaan ekspresi budaya tradisional yang mendapat perlindungan, kepemilikan atau pemegang hak cipta atas ekspresi budaya tradisional, mekanisme pemanfaatan ekspresi budaya tradisional, sistem perlindungan ekspresi budaya tradisional, dan ketentuan larangan dan sanksi.

\section{DAFTAR PUSTAKA}

Arif Lutviansori, 2010, Hak Cipta dan Perlindungan Folklor di Indonesia, Yogyakarta: Graha Ilmu

Hans Kelsen, Teori Umum tentang Hukum dan Negara, (Bandung: Nusa Media, 2013)

Hans Nawiasky dalam Maria Farida Indrati, 2006, Ilmu Perundang-undanganDasar-dasar dan Pembentukannya, Yogyakarta: Kanisius

Maya Sofia dan Tasya Paramitha, Upaya Pemerintah Agar Budaya Indonesia Tak Diklaim Negara Lain, diakses dari www.life.viva.co.id pada tanggal 22 Desember 2013

P.V Valsala G Kutty, National Experiences With The Protection of Expression of Folklore/Traditional Cultural Expression, WIPO Publication

Rahmi Jened, 2010, Hak Kekayaan Intelektual, Surabaya: Penerbit Universitas Airlangga

Satjipto Raharjo, Ilmu Hukum, (Bandung: Citra Aditya Bakti, 2000),

Suyud Margono, 2010, Hukum Hak Cipta Indonesia: Teori dan Analisis Harmonisasi Ketentuan WTO-TRIPs Agreement, Bogor: Ghalia Indonesia

Syafrinaldi, Sejarah dan Teori Perlindungan Hak Kekayaan Intelektual, Al Mawarid edisi IX Tahun 2003, hal 6

Tim Lindsey,dkk (ed.), 2011, Hak Kekayaan Intelektual Suatu Pengantar, Bandung: PT Alumni hal. 96

W.Friedman, Teori dan Filsafat Hukum, (Jakarta: CV Rajawali), 
WIPO Publication, Consolidated Analysis of The Legal Protection of Traditional Cultural Expression/Expression of Folklore, May 2003,

www.antaranews.com, Warisan Budaya Indonesia Rawan Diklaim Negara Lain, diakses pada tanggal 23 Desember 2013

www.portalindonesiaku.blogspot.com, Data Budaya Indonesia yang Diklaim Negara Lain, diakses pada tanggal 23 Desember 2013

www.wikipedia.com, “Kompilasi” diakses tanggal 30 Desember 2013 